\title{
Study on the Order Dimension of Social Governance and Social Policy
}

\author{
Lele Qi \\ Changchun University of Technology, Changchun, 130012
}

Keywords: social governance, social policy, order dimension

\begin{abstract}
In the early years of reform and opening-up, Deng Xiaoping had foreseen the theme and development and peace of the $21^{\text {st }}$ Century. With the development of the times, although war still exists in today's world, worldwide national order, as well as professional and market order have become the core of development. In other words, peace has become the theme of the world, representing all people's aspiration for peace. The maintenance of a good social order is a prerequisite for the stable development and progress of the world, whose completion requires the assistance of a harmonious and beautiful social policy. At the same time, society needs innovative ways of governance to ensure that social policies can keep pace with the times. In short, there are subtle links between social governance, social policy and social order. This paper aims to explore their relationships.
\end{abstract}

\section{Introduction}

Since ancient times, China has been carrying out exploration and research on social governance. Today, social governance has become one of the hot topics. Over the years, numerous scholars have conducted in-depth discussions on social governance in various aspects, but so far there is no unified views, while everyone holds different opinions. People are always obsessed with foreign literature, based on which, they try to find answers. However, they often tend to forget to combine the actual national conditions, which directly leads to narrow views on society. From the point of view of appropriate order, it is required to make use of the wisdom of the ancients to regulate social order and arrange the order dimension in connection with the national conditions of modern China, so as to innovate governance in exploration.

\section{Realistic Orientation of Social Governance.}

The meaning of social governance is rich and all-encompassing, whose implications and external expansion often change with what we hear, think and see. The most changeable among those is the psychological changes of observer, descriptor and listener, who always subconsciously produce psychological inclination before observing, describing and listening. This leads to the fact that the objective facts of things cannot be found, and then the description of the concept of social governance will be different.

Different perspectives have different concerns about social governance, so the realization of social governance often has significant characteristics due to different perspective of observation. Among them, since government's cognition of social governance is quite similar to public governance, elements contained in them also have many similarities with the mandatory characteristic. And if we start from the whole society to think about social governance, the results will be very different from the former. First of all, there is a fundamental difference between the government and society. The government needs dignity and public conviction. Therefore, it has to resort to universal mandatory forms to treat social governance. We can compare the society to a huge organization which constantly progresses in order to improve the level of life development. Our society needs obscure service providers and also management decision makers. In the process of managers participating in social affairs and making decisions, social governance will have a great impact. For the bureaucratic level of social organizations, social governance will be involved in the structure of management itself and the direction, speed and quality of future development of society 
that it determines.

Part of the effect of social governance is to establish and expand a certain order. In this respect, the internal governance of enterprises to a certain extent can be seen as a part of social governance. Work contents of companies in the fields of property, security, cleaning and garbage disposal have become an important part of social governance. The work contents of this type of companies are closely related to the health and safety of people which is aimed to achieve by social governance. Meanwhile, companies themselves relate to people's life in the community and the work of employees.

If we classify and analyze social governance, we can divide society into urban and rural areas. The planned economy in the countryside in the period of exploring social system since the founding of the People's Republic of China has made the rural economy depressed. Since the reform and opening up, China's economy has been developed by leaps and bounds. But in the process of rapid development of the national economy, the gap between urban and rural areas is constantly increasing. Compared with the rapid development of cities, the market order in rural areas has always been stagnant, and no market order suitable for the development of rural economy has been formed. The economic and cultural impact bringing about by reform and opening up has not produced a great economic transformation here, therefore, there are still many social governance problems and challenges. The number of people in the countryside is a drop in the bucket compared with that in the cities, but no matter how many or how small the number is, people always accept social governance. There are village committees in rural areas, while in cities there are neighborhood committees, police stations and so on. China is a country with a large population and a vast territory, which has brought certain difficulties to social governance. Therefore, our country is even more necessary to maintain a stable and harmonious order of life, since reasonable order will bring convenience to social governance. Combining with the characteristics that social governance covers too many affairs, it is necessary to make a clear and accurate positioning of social governance.

\section{Standard Orientation of Social Governance.}

Prosperous country and peaceful people are good wishes and hopes of the Chinese nation since ancient times. In the $21^{\text {st }}$ century, this ideal is embodied to build a harmonious society. To realize this ideal, we need to make it clear that social construction and social management will be an indispensable prerequisite for building a harmonious socialist society. Only by establishing a social system that adapt to the socialist economic, can a social order political and cultural system that is compatible with the socialist economic, political and cultural order be formed. It is expected to combine government management with social autonomy, establish a new pattern of social management, namely, Party committee leadership, government responsibility, social coordination and public participation. The government should change its functions from the direct "administrator" of the society to the "dominator" of the social governance step by step, devote itself to creating an equal competitive market environment and a harmonious social environment, better coordinate the relationship between economic development and social development, and better provide the society with what the market mechanism can not provide, including economic public goods, social public goods and institutional public goods, to better safeguard social and political stability.

In short, from the perspective of a good society, social governance is a normative concept. Good social governance means that people are hard-working with a good quality of life and room for growth, creation, hard work, as well as a good incentive. It also means that the public interest can be taken care of by everyone's efforts. It has a good operating structure at the institutional level, which can resolve various contradictions and coordinate various interests. Here, everyone is equal. In terms of ability, there are good social services to solve everyday problems. Political order, state order and market order are very important, and governance structure of the society itself is also very significant. Good social policies are more vital for modern social governance. 


\section{Social Policy of Order Dimension}

Good social policy will add to economic development and human progress. The United States today is a good example, which is why social policy has been valued by many sociologists. However, today's social policies tend to overstretch and over strengthen the national order, depriving social policies of freedom and often destroying truly effective social policies. In the order dimension of primitive social policy, emphasis is on ensuring the safety of life and the basic living conditions, while at the same time emphasizing mutual assistance. This is also the reason why we have the traditional virtues of be willing to help others of the Chinese nation.

On the other hand, society has never been the life of a person or a family, in other words, life needs to be expanded. There are many people in every country in the world who have a hard life, and even in the United States, there are tramps. They may be physically disabled, may be old and weak, may not be able to work or have a low income due to low ability. Difficulties in economic and social relations make their wanderings and lives difficult. Even other people's kindness can not make them out of this state of life. But the corresponding extended social relief mechanism can organize a large number of human and material resources to help them systematically and comprehensively through a variety of activities. The frequent holding of these activities is a small step in expanding social innovation, a manifestation of national centripetal force, and more importantly, social progress and development. In addition, businessmen devoting own strength to helping the poor is a manifestation of the original market order of rescue function. This also reflects the social policy function contained in the original market order.

Social policy's support for market development is a win-win situation for both the market and society. The global market for products, cheap food and clothing provides low-income people with a large number of consumer goods while providing them a large number of jobs around the world. The greatest surprise is the dramatic decline in the number of people living in poverty worldwide, which is the best proof that good cooperation between market order and social policy can achieve win-win results. Today's Internet markets and express delivery systems, which bring distant producers into the global market, also help the poor become rich.

\section{Social Governance Innovation of Order Dimension.}

Under the circumstances of rapid marketization, high economic development and large-scale population flow, China has ensured political stability and social development, and at the same time has provided a basis for social governance for economic development. From the dimension of order, China's current social governance innovation needs to pay attention to following several aspects.

This dimension is also called the dimension of the Communist Party of China, reflected in the Party building at the grass-root level. Party building at the grass-root level is the foundation of the Party's primitive order and also the focus of the Party's mass line. As a long-term ruling party, the core order of the Party is the dimension of expanded political order. In this era, person who has obtained the connection with the primitive order, thus gaining the support of the primitive social forces, can obtain the basic political power, that is, the power of people's support, so as to has a strong basis for the legitimacy of governance. Many governance innovations of social grass-roots are focused on Party building innovations, which have very important social and political development significance.

This is also called the dimension of government order. In this area, it involves two aspects. One aspect is the social management innovation of government at grass-root level. In this respect, the penetration of urban government into society is relatively strong, while the relationship between the grass-root government and society in rural society is relatively loose. These two areas involve innovation.

China's market development is a process of gradual development and evolution. The reform of rural contract system has activated the vitality of the commodity market and society, and then initiated the innovation of China's social governance in the dimension of market order. China's grassroot villagers' autonomy and neighborhood committee autonomy have also begun 
experimental innovation. Until now, grassroot elections have become a major landscape of grassroots social governance.

\section{Conclusion}

Today in the $21^{\text {st }}$ century, we have a common dream that is the Chinese Dream, which is a huge project and requires the joint efforts and struggle of our people. To realize it, we need a harmonious and beautiful society, a good social policy and an appropriate dimension of order. The realization of these three is one of the powers to build Chinese dream. To adjust firmly according to the national conditions, we are expected not to be just confined to a certain level of society but to endeavor to see the overall situation, and closely follow the characteristics of the times.

\section{References}

[1] Feng Yuan. Social Work's Participation in Social Governance in the New Period: Theoretical Basis, Power Source and Path Selection [J]. Social Construction, 2017,4(06): 29-38.

[2] Zhang Yifei, Zheng Li. Why does "Society" Need "Governance"-Origin and Enlightenment of Western Social Governance Problems [J]. Journal of Social Sciences, Hunan Normal University, 2017, 46 (04): 102-109.

[3] Research Center for Coordinative Innovation of Social Governance and Social Policy: Serving Government Decision-making and Policy Consulting to Promote Social Policy Innovation and Social Development [J]. Journal of Xi'an Jiaotong University (Social Science Edition), 2016,36 (06): $2+137$.

[4] Huan Pingqin. Welfare Society Construction and Social Governance-Concurrently on the Theoretical Consciousness of Social Policy Research [J]. Teaching and Research, 2015 (11): 21-29.

[5] Xiong Yuegen. Social Policy Implementation as Social Governance: the Combination of Technical Rationality and Political Practice [J]. Jianghai Journal, 2015 (04): 104-110. 